\title{
The Effects of Scenario-Based STEM Project Design Process with Pre-service Science Teachers: 21st Century Skills and Competencies, Integrative STEM Teaching Intentions and STEM Attitudes
}

\author{
Huriye Deniş Çeliker (Corresponding author) \\ Department Science Education, Faculty of Education, Burdur Mehmet Akif Ersoy University \\ İstiklal Yerleşkesi, 15030 Burdur, Turkey
}

Tel: 90-248-213-4083Ｅ-mail: huriyedenis@mehmetakif.edu.tr

Received: November 28, 2020 Accepted: December 24, 2020

Published: December 31, 2020

doi:10.5296/jei.v6i2.17993 URL: https://doi.org/10.5296/jei.v6i2.17993

\begin{abstract}
The purpose of this study is to determine the effects of the scenario-based STEM project design process on pre-service science teachers' perceptions of 21 st-century skills, competencies, integrative STEM teaching intentions, and STEM attitude. In the study, a pretest-posttest quasi-experimental design, which does not contain a control group, was used. The participants of the research are 66 fourth-grade pre-service science teachers in the south-west of Turkey. The 21 st-century skills and competencies scale and an integrative STEM teaching intentions questionnaire, and a STEM attitudes scale were used as a pre-test and post-test. Pre-service teachers designed projects using engineering design processes to solve the problems in the scenarios given to them. In the analysis of the data, paired-samples t-test and Wilcoxon Signed Rank Test were applied using SPSS-21. The results show that designing a scenario-based STEM project certainly contributed to the 21st-century skills competence perceptions, STEM teaching intentions, and STEM attitudes of pre-service science teachers.
\end{abstract}

Keywords: 21st-century skills, Integrative STEM teaching intentions, Scenario-based STEM project, STEM attitudes 


\section{Introduction}

\subsection{Introduce the Problem}

For a productive society, individuals who can think critically, use research-inquiry skills, solve problems, make designs, produce and think creatively; in short, they must be equipped with the skills required by 21 st-century. Such societies can reach the power to compete with other nations (Morrison, 2006; Wai, Lubinski, \& Benbow, 2010; Akgündüz et al., 2015; White, 2014; Gunn, 2017; Aydın, Saka, \& Guzey, 2017). In the new century, the demand with the changing situations, different human needs, and problems arise for this commitment for qualified people who offer particular solutions to these questions is increasing. Therefore, STEM-integrated education is becoming more important for people around the world (Kumtepe \& Genc-Kumtepe, 2014; Ministry of Education, 2016). Leading countries, exclusively known as global powers, need to have innovative industry fields and qualified STEM graduates who can solve these problems and compete globally (Kanematsu \& Barry, 2016). Science, Technology, Engineering, and Mathematics (STEM), STEM aims at a production-oriented education approach along with providing high-level skills necessary in 21st-century (Moomaw \& Davis, 2010; Oner et al., 2014). Thus, STEM education has an essential role for individuals to gain 21st-century skills (R. M. Capraro, M. M. Capraro, \& Morgan, 2013; Baran, Canbazoğlu-Bilici, \& Mesutoğlu, 2015; Yıdırım, 2016; Çevik, Danıştay, \& Yağc1, 2017). Being successful in STEM fields reflects the sophistication and economic power in science and technology and directs the necessary conditions of our lives as citizens, consumers, employees, and parents (National Research Council [NRC], 2011). STEM education aims to provide students with environments where they can gain experience and to enable them to become engineers, technologists, or scientists of the future because STEM education stands on solving problems by using daily life examples instead of using traditional education programs (Breiner, Harkness, \& Johnsonand-Koehler, 2012).

Not only are the conditions different nowadays, but the real-world demands are also very different from what applies to teachers and employers (Anugerahwati, 2019). Teachers' knowledge of only one area without interdisciplinary work and their specialization is insufficient to raise individuals who are suitable for the 21 st-century skills of countries (Çorlu, R. M. Capraro, \& M. M. Capraro, 2014). STEM education enables students to become competent by gaining the necessary skills for the 21 st century (Tsupros, Kohler, \& Hallinen, 2009; Ibrahim \& Halim, 2013). In STEM learning environments, social interaction between students is more enthusiastic. It supports the improvement of 21 st-century skills by developing expertise in collaboration, inquiring, critical thinking and problem-solving (Sanders, 2009; Şahin, Ayar, \& Adiguzel, 2014; Khalil \& Osman, 2017). The combination of 21 st-century skills and the STEM program is equally critical. This combination can apply to students at all school levels (Kay, 2009; Rotherham \& Willingham, 2009). Although teachers know the advantages of the STEM education approach, they feel inadequate to use it in practice (Hsu, Purzer, \& Cardella, 2011; Hacıŏlu, Yamak, \& Kavak, 2016a; Özbilen, 2018). Pre-service teachers have basic knowledge of engineering discipline, but they are insufficient in the scope of integrating engineering with science and technology disciplines (Marulcu \& Sungur, 2012). In this context, there is a need for teachers to be equipped with STEM 
education during their in-service or pre-service education to raise qualified individuals (Han, Yalvaç, R. M. Capraro, \& M. M. Capraro, 2015; Hacıoğlu, Yamak, \& Kavak, 2016b; Özçakır-Sümen \& Çalışıcı, 2016). Science teachers need to learn how to ease STEM implementation, and to improve both attitudes and skills toward interdisciplinary teaching (Salami, Makela, \& Miranda, 2017).

The related literature demonstrates that the problem-solving skills, and critical thinking skills of pre-service science teachers who received STEM education increased positively (Öztürk, 2018). Design and engineering-based STEM education practices have improved the leadership skills and perceptions of teachers and pre-service teachers regarding teaching competencies (Pinnell et al., 2013). There was a significant increase in the learning level of pre-service science teachers in the lessons conducted with STEM (Y1ldirım \& Altun, 2015). As a result of STEM-based education, pre-service science-mathematics teachers think that activities are efficient, educationally effective and fun (Y1lmaz \& Pekbay, 2017). As a result of the engineering design-based science education process, science teachers emphasize that they will benefit from engineering-based science education in their teaching (Bozkurt, 2014). There is a significant difference in STEM definitions before and after the STEM application of pre-service teachers, which changed as 'STEM is an integrated education approach' (Aslan-Tutak, Akaygün, \& Tezsezen, 2017). It positively affected students' attitudes as a result of the training in which project-based learning activities and STEM education were integrated (Bingolbali, Monaghan, \& Roper, 2007). Attitudes towards STEM education are essential for individuals to acquire 21st-century skills and achieve success in STEM education in their future lives (Alıc1, 2018). Studies show a significant difference in favor of post-tests in the attitudes of the study group of STEM-based education at different education levels towards STEM education (Uğraş, 2018; Rehmat, 2015; Karışan \& Yurdakul, 2017; Reid-Griffin, 2019; Wahono \& Chang, 2018; Sivrikaya, 2019). The fact that teachers have different perceptions about STEM integration causes differences in STEM education integration applied in lessons (Wang, Moore, Roehrig, \& Park, 2011). STEM attitudes of the pre-service teachers who will raise the generations of the future will enable them to make inferences about how they will promote the next generations. The positive attitudes of the pre-service teachers about STEM education show that students who display a positive perspective towards STEM education and have a tendency towards these fields can be a boost in the future (Gelen, Akçay, Tiryaki, \& Benek, 2019). Thus, revealing the 21st-century skills competence perceptions of pre-service teachers and their STEM attitudes and STEM teaching intentions will render an insight into how they will shape the future. Based on this, the present study aimed to determine the effect of developing scenario-based STEM projects with pre-service science teachers on 21st-century skills and perceptions, STEM teaching intentions, and STEM attitude. The dependent variables of the study are 21 st-century skills and competencies, integrative STEM teaching intentions, and STEM attitudes of pre-service teachers. The independent variable is the scenario-based STEM project design process. The research questions are presented as follows:

- Does the scenario-based STEM project design process make significant differences in pre-service science teachers' perceptions of 21 st-century skills and competencies? 
- Does the scenario-based STEM project design process make significant differences in pre-service science teachers' integrative STEM teaching intentions?

- Does the scenario-based STEM project design process make significant differences in the STEM attitudes of pre-service science teachers?

\subsection{Conceptual Framework}

The conceptual framework of the research was prepared by revising A Conceptual Framework for the Integration of 21st Century Skills in Biology Education based on literature by Hiong and Osman (2013) and is presented in Figure 1. One of the basic principles of the constructivist approach is students' constructing new insights actively instead of taking and assimilating facts passively. Consistent with this view, different classroom techniques are required to help students learn essential and complex system of ideas (Jacobson \& Wilensky, 2006). Inquiry-based-learning proposes learning environments that promote inquiry, thoughtful research, interpretation of information, and the development of new insights (Diggs, 2009). Problem-based learning indicates that learning environments should involve students in related and original problems to increase the significance of the subject matter to be taught (Christensen, Knezek, \& Tyler Wood, 2015). Project-based learning is an exhaustive approach to classroom teaching designed to involve students in researching real problems (Blumenfeld et al., 1991). The integration of STEM content entails the use of learning objectives, facilitation, and application from various STEM disciplines. To ensure the integration, learning goals and learning projects from mathematics, science and technology should be defined and a connection should be determined between intimately associated concepts in various disciplines (Bryan, Moore, Johnson, \& Roehrig, 2015). From an educational perspective, there may be a variety of activities in STEM but generally it involves replacing traditional lesson-based teaching strategies by more research and project-based approaches (Breiner, Harkness, Johnson, \& Koehler, 2012). Twenty first century skills which are identified as collaboration, digital literacy, critical and creative thinking, and problem-solving considered certainly to be connected with the competencies believed to be taught by schools to help students succeed in today's world (Motallebzadeh, Ahmadi, \& Hosseinnia 2018). STEM teaching intentions can be defined as the voluntariness of teacher candidates to use STEM-based teaching in their lessons and to claim to have a teaching style propped up a multidisciplinary approach (Günbatar \& Bakırc1, 2019). Attitude can be defined as an individual's (or a group's) developing a positive, negative, or neutral emotion towards an object, a state or a behavior (Pryor, Pryor, \& Kang, 2015). Based on this definition, STEM attitudes can be understood as a positive, negative, and neutral feeling towards STEM. 


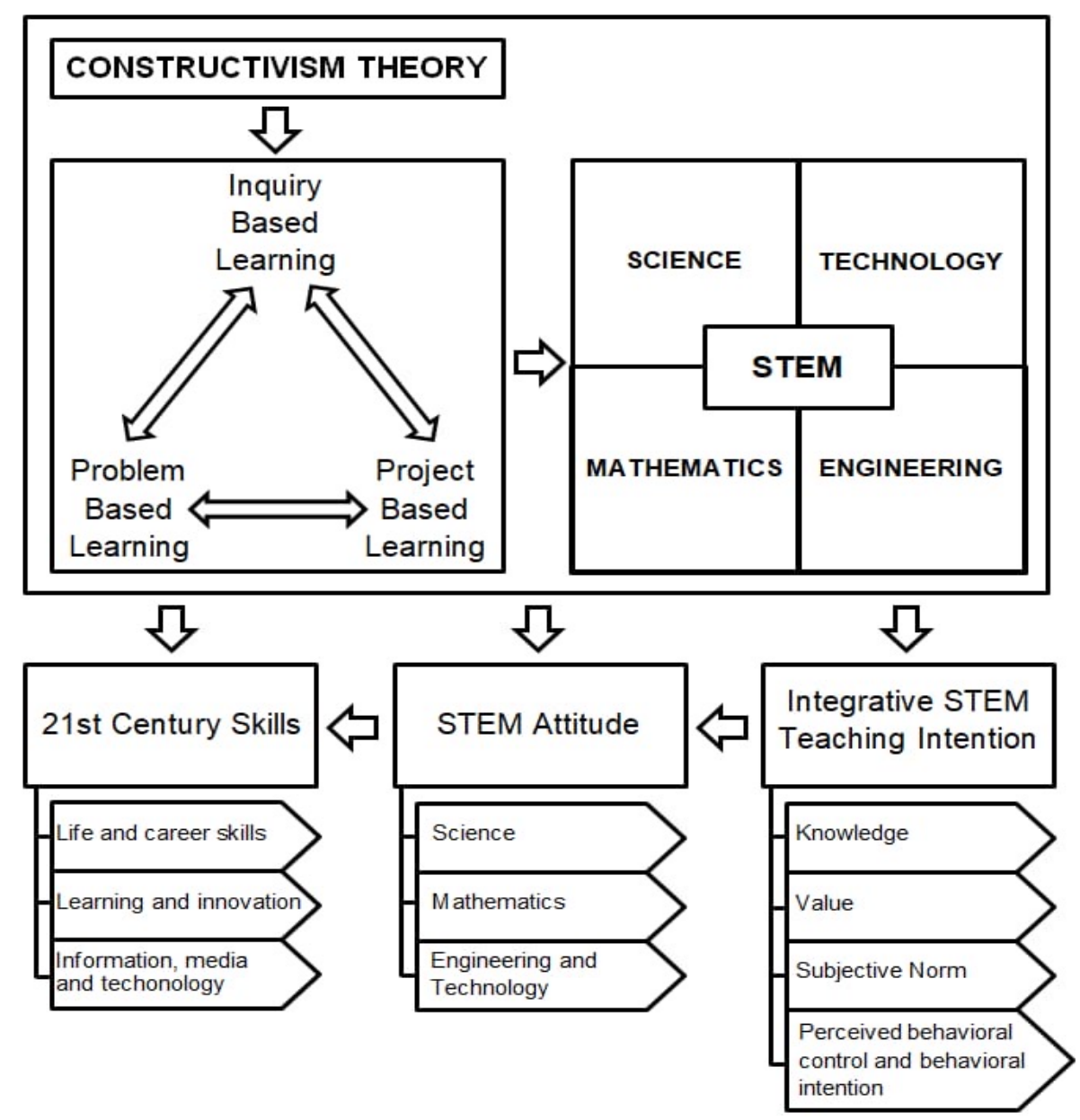

Figure 1. Conceptual Framework of the Research

\section{Method}

\subsection{The Research Design}

In the present study, a pretest-posttest quasi-experimental design without a control group was used (Cook \& Campbell, 1979). This model is one of the pre-trial models. In this model, an independent variable is applied to the determined group (Karasar, 2010). In this design, the effect of the experimental process is tested with a study on a single group, and the measurements of the subjects regarding the dependent variable are obtained by using the same subjects and the same measurement tools as a pre-test before the implementation and the post-test after the implementation. There is no randomness and matching, and in this respect, the research design can be defined as one-factor within-groups or repeated measures design. In the design, the significance of the difference between the pre-test and post-test values of a single group is analyzed (Büyüköztürk et al., 2008). The scenario-based STEM project design process was used as an experimental process in the study. The 21 st Century skill perceptions scale, STEM attitudes scale, and Integrative STEM Teaching Intentions questionnaire were used as pre-test and post-test. 


\subsection{Participants}

The implementation process of the study was carried out in Creating Projects in Secondary School elective course in a faculty of education of a state university in the southwest of Turkey. seventy two pre-service teachers who were 4th-year students within the Department of Science and Mathematics Education participated in the research. Of these, 66 pre-service teachers answered the questionnaire voluntarily. The research was carried out in the spring semester of 2020. As for the gender distribution, $78.79 \%(n=52)$ of the participants were female while $21.21 \%(\mathrm{n}=14)$ were male.

\subsection{Data Collection Instrument}

2.3.1 Twenty First Century Skills Century Skills Competence Perceptions Scale for Pre-service Teachers

21 st Century Skills Competence Scale for Pre-service Teachers developed by Anagün, Atalay, Kilıç, and Yaşar (2016) to determine the 21st-century skill perceptions were used to collect data. The scale consists of three sub-factors. These are: learning and innovation skills factor; life and career skills factor; and knowledge, media, and technology skills factor. Cronbach alpha coefficient of the inventory, which is formed by 42 Likert-type items, was found to be .88. Cronbachs' alpha values of each sub-factor of the scale are shown in Table 1.

Table 1. Sub-factors, examples of items, and Cronbach alpha values of 21st Century Skills and Competencies Scale

\begin{tabular}{|l|l|l|}
\hline $\begin{array}{l}\text { Sub-factors of 21st Century } \\
\text { Skills and Competencies Scale }\end{array}$ & Examples of items & Original Cronbachs'Alpha \\
\hline Learning and Innovation Skills & $\begin{array}{l}\text { I synthesize by establishing relationships } \\
\text { between knowledge and arguments. }\end{array}$ & 0.85 \\
\hline Life and Career Skills & I listen to what others think on a topic. & 0.83 \\
\hline $\begin{array}{l}\text { Information, Media and } \\
\text { Technology Skills }\end{array}$ & $\begin{array}{l}\text { I use the appropriate media tool } \\
\text { to get information. }\end{array}$ & 0.81 \\
\hline
\end{tabular}

\subsubsection{STEM Attitudes Scale}

STEM Attitudes Scale developed by Faber, Unfried, Wiebe, Corn, Townsend, and Collins (2013) and adapted to Turkish by Yildırım and Selvi (2015) was used. The Turkish version of the STEM Attitudes Scale consists of four factors (Science, Engineering, 21st Century skills, Mathematics) and 37 items in total. Cronbach's alpha coefficient of the inventory was found to be 0.94 . Cronbachs' alpha values of each sub-factor of the scale are shown in Table 2. 
Table 2. Sub-factors, examples of items and Cronbach alpha values of STEM Attitude Scale

\begin{tabular}{|l|l|l|}
\hline $\begin{array}{l}\text { Sub-factors of STEM } \\
\text { Attitude Scale }\end{array}$ & Examples of items & Original Cronbachs'Alpha \\
\hline Science & $\begin{array}{l}\text { Science is important to me in the } \\
\text { work of my life. }\end{array}$ & 0.86 \\
\hline Engineering and Technology & I take care of how the machines work. & 0.86 \\
\hline Mathematics & Math is a difficult lesson for me. & 0.89 \\
\hline 21 st century skills & $\begin{array}{l}\text { I am sure that I can manage my time } \\
\text { wisely while working on my own. }\end{array}$ & 0.89 \\
\hline
\end{tabular}

\subsubsection{Integrative STEM Teaching Intentions Questionnaire}

The Integrated STEM Teaching Intentions Scale developed by Lin and Williams (2015) was adapted into Turkish by Haciömeroğlu and Bulut (2016). The Turkish form of the adapted scale consists of 31 items and is a 7-point Likert type. Cronbach's alpha coefficient for the overall instrument was calculated as 0.94 . Cronbachs' alpha values of each sub-factor of the scale are shown in Table 3.

Table 3. Sub-factors, examples of items and Cronbach alpha values of Integrative STEM Teaching Intention Scale

\begin{tabular}{|l|l|l|}
\hline $\begin{array}{l}\text { Sub-factors of Integrative STEM } \\
\text { Teaching Intention Scale }\end{array}$ & Examples of items & $\begin{array}{l}\text { Original } \\
\text { Cronbachs'Alpha }\end{array}$ \\
\hline Knowledge & $\begin{array}{l}\text { I am familiar with primary school science } \\
\text { (Newton's laws of motion). }\end{array}$ & 0.93 \\
\hline Value & $\begin{array}{l}\text { I think it is important to help students learn how to } \\
\text { collect data about STEM in the learning process. }\end{array}$ & 0.86 \\
\hline Attitude & $\begin{array}{l}\text { If the school environment is in this direction (the } \\
\text { request of the administrators, the school's physical } \\
\text { and technological equipment), I use STEM in my } \\
\text { lessons in the learning-teaching process. }\end{array}$ & 0.87 \\
\hline Subjective norm & $\begin{array}{l}\text { I think I have enough skills to use STEM in the } \\
\text { learning-teaching environment. }\end{array}$ & 0.69 \\
\hline $\begin{array}{l}\text { Perceived behavioral control } \\
\text { and behavioral intention }\end{array}$ & $\begin{array}{l}\text { In the learning-teaching process, we can train the } \\
\text { talented students of the future by using STEM. }\end{array}$ & 0.86 \\
\hline
\end{tabular}




\subsection{Data Analysis}

The data were analyzed in SPSS 21 package program. Whether the data obtained with the scales had a normal distribution was investigated. When Kolmogorov-Smirnov test results and skewness and kurtosis values were examined, it was determined that the pre-test and post-test data of the 21st-century competence perceptions scale were suitable for normal distribution, the STEM teaching orientation scale and the STEM attitudes scale were not suitable for the normal distribution. The paired sample t-test was used for comparing the pre-test and post-test scores of the 21st-century efficacy scale. Wilcoxon Signed Rank Test for Paired Samples, one of the non-parametric analyses, was used to compare the STEM teaching orientation scale and STEM attitudes scale pretest-posttest scores.

\subsection{Experimental Manipulations or Interventions}

The experimental application was carried out with pre-service science teachers in the spring semester of the 2019-2020 academic year in the "Elective Course: Creating a project in the secondary school" course. In this course, pre-service teachers were informed about project-based learning, problem-based learning, inquiry-based learning, STEM, and application examples for seven weeks (14 lesson hours). Four weeks ( 8 lesson hours) of these applications were carried out with face-to-face training. The pandemic was declared while the experimental practice was in progress. Turkey, like the entire world, has taken precautions against the Covid-19 outbreak. After the first Covid-19 diagnosis of a person in Turkey, The Council of Higher Education has suspended the courses at universities for three weeks. After these three weeks, it has been announced that the 2019-2020 spring semester will be completed through distance education (Görgülü-Arı \& Hayır-Kanat, 2020). For this reason, 3 weeks (6 lesson hours) of the theoretical courses were conducted using the Adobe Connect application by logging in the distance education unit of the university where the research was conducted. The 6-week STEM project preparation process was likewise continued through distance education. The pre-service teachers were given four different scenarios including daily life problems. Various books were used to select the scenarios (Çepni, 2018; Yıldırım, 2018). As there may be difficulties in accessing certain project materials during the pandemic, the pre-service teachers were allowed to choose the scenario they wanted to carry out. Problem-based learning approach and scenarios have been used with STEM education in recent years, especially in activity design studies (Gülgün, Yılmaz, \& Çağlar, 2017). The best way to achieve STEM integration is to carry out the activities within the scope of the engineering design process (Felix, Bandstra, \& Strosnider, 2010). Hence, pre-service teachers prepared their projects according to the Engineering in Elementary (EiE) design process shown in Figure 2 (Cunningham, 2009). In the project preparation process carried out through distance education process, inquiry-based questions were asked to pre-service teachers every week. Thus, the pre-service teachers created STEM projects with an approach by combining problem-based learning, project-based learning, and inquiry-based learning. As a result, they presented the STEM projects they created based on the scenarios in the format of video recording. Since the process was carried out through distance education, the pre-service teachers prepared their projects individually. The pre-service teachers created projects obtaining different energy sources, creating a habitable city plan, a solar-powered car, 


\section{Macrothink}

a hydroelectric power station based on the scenarios. Before the experimental application (face-to-face) and after the experimental application (through a distance learning environment), the 21st-century skills competence perceptions scale, the STEM attitudes scale, and the Integrative STEM Teaching Intentions Questionnaire were applied as pre-test and post-test. The pre-service teachers used nicknames while answering the scales items.

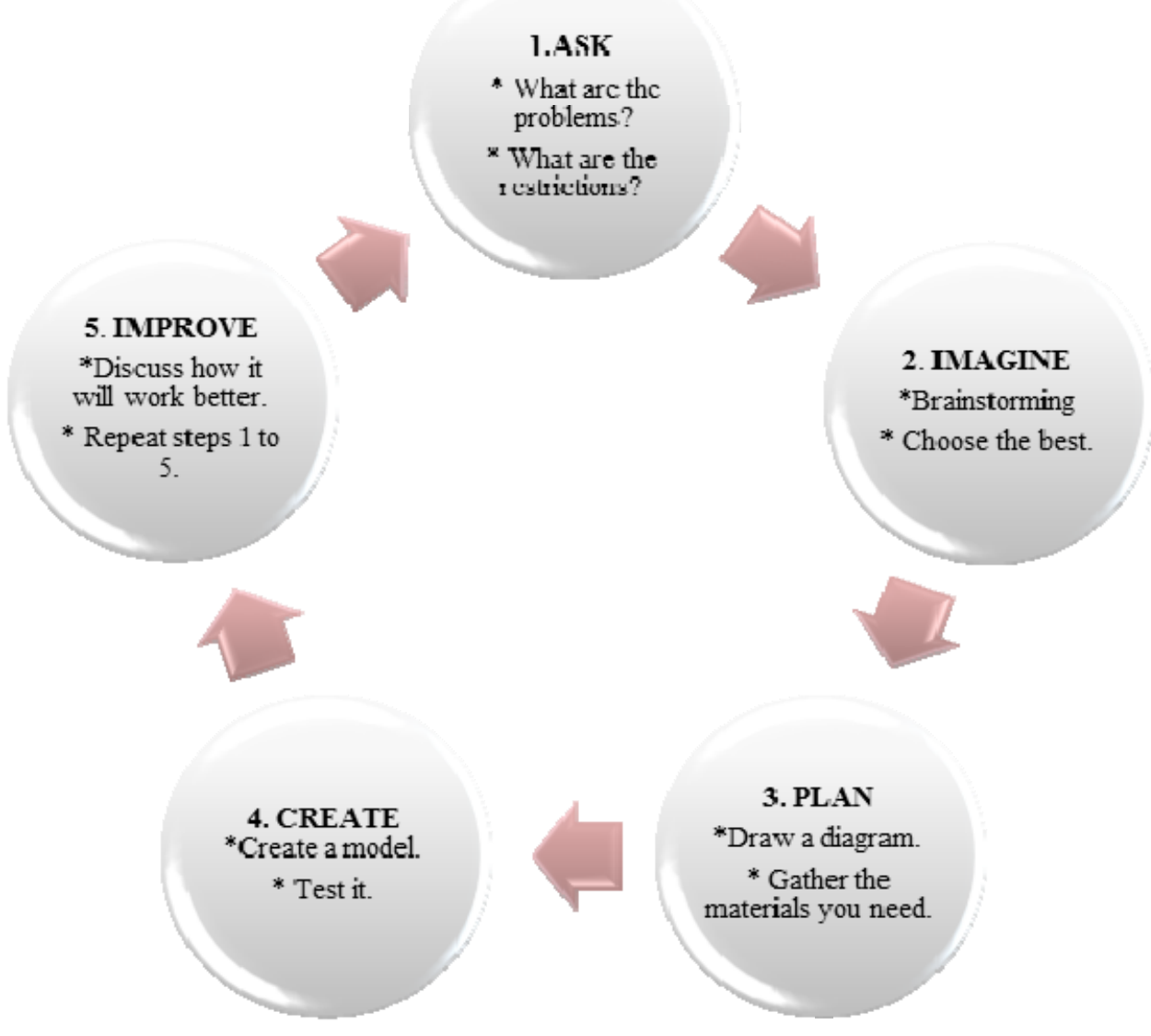

Figure 2. The Engineering in Elementary (EiE) engineering design process (Cunningham, 2009)

\section{Results}

Arithmetic means and standard deviations of pre-test and post-test scores pre-service science teachers have achieved from 21st Century Skills and Competencies Scale and its sub-factors are given in Table 4. 


\section{Ml Macrothink}

Table 4. Arithmetic means and standard deviations that pre-service teachers have achieved from 21st Century Skills and Competencies Scale and sub-factors

\begin{tabular}{|l|l|l|l|l|}
\hline \multirow{2}{*}{ 21st Century Skills and Competences Scale and sub-factors } & \multicolumn{2}{|c|}{ Pre-Test } & \multicolumn{3}{c|}{ Post-Test } \\
\cline { 2 - 5 } & Mean & SD & Mean & SD \\
\hline Learning and Innovation Skills Sub-factor & 67.63 & 9.05 & 72.18 & 8.98 \\
\hline Life and Career Skills Sub-factor & 66.59 & 5.72 & 68.78 & 5.49 \\
\hline Information, Media and Technology Skills Sub-factor & 34.42 & 4.13 & 35.31 & 3.44 \\
\hline Total Inventory & 168.65 & 15.34 & 176.28 & 14.95 \\
\hline
\end{tabular}

As a result of pre-service teachers' scenario-based STEM project design, there was a significant increase in their 21 st-century skills [ $\mathrm{t}(65)=6.34, \mathrm{p}<.01]$. While the average of the 21 st-century skill of pre-service teachers was 168.65 before the application, after the implementation of scenario-based STEM project design it increased to 176.28. This finding showed that scenario-based STEM project design had a meaningful effect on increasing the 21 st-century skills of pre-service teachers. In addition, Cohen d effect size was 0.781 , and $\eta^{2}$ (et square) effect size was 0.38 . Therefore, the difference between the means was 0.78 standard deviation and the $38 \%$ of the variant that belongs to the 21 st-century skills scores emerged depending on the pre-test post-test, namely measurement. Measured effect sizes reflect a large effect. As a result of pre-service teachers' designing scenario-based STEM projects, there was an increase in the sub-factors of Learning and Innovation Skills $[\mathrm{t}(65)=$ $6.02, \mathrm{p}<.01]$. Furthermore, there was an increase in sub-factors of life and career skills [ $\mathrm{t}(65)$ $=5.03, \mathrm{p}<.01]$ and information, media, and technology skills $[\mathrm{t}(65)=3.39, \mathrm{p}<.01]$.

T-test results conducted on the significance of the difference between pre-test and post-test average scores of 21st Century Skills and Competencies Scale are given in Table 5. 


\section{I Macrothink}

Table 5. T-test Results of Pre-test Post-test for 21st Century Skills and Competencies Scale and sub-factors

\begin{tabular}{|c|c|c|c|c|c|}
\hline 21st Century Skills Scale and sub-factors & Measurement & $\mathrm{N}$ & sd & $\mathrm{t}$ & $\mathrm{p}$ \\
\hline \multirow{2}{*}{ 21st Century Skills and Competences } & Pre test & \multirow{2}{*}{66} & \multirow{2}{*}{65} & \multirow{2}{*}{6.34} & \multirow{2}{*}{.000} \\
\hline & Post test & & & & \\
\hline \multirow{2}{*}{ Learning and Innovation Skills } & Pre test & \multirow{2}{*}{66} & \multirow{2}{*}{65} & \multirow{2}{*}{6.02} & \multirow{2}{*}{.000} \\
\hline & Post test & & & & \\
\hline \multirow{2}{*}{ Life and Career Skills } & Pre test & \multirow{2}{*}{66} & \multirow{2}{*}{65} & \multirow{2}{*}{5.03} & \multirow{2}{*}{.000} \\
\hline & Post test & & & & \\
\hline \multirow{2}{*}{ Information, Media and Technology Skills } & Pre test & \multirow{2}{*}{66} & \multirow{2}{*}{65} & \multirow{2}{*}{3.39} & \multirow{2}{*}{.001} \\
\hline & Post test & & & & \\
\hline
\end{tabular}

Wilcoxon Signed-Rank test results were given in the Table 5 that is about if the STEM attitudes of pre-service science teachers show a significant difference before and after the process of designing a scenario-based STEM project. The result of the analysis shows that there is a significant difference between pre-service science teachers' pre-test and post-test scores in the STEM attitudes scale, $\mathrm{z}=5.27, \mathrm{p}<.05$. When the mean rank and sum of ranks are taken into consideration, they evidence that this difference is in support of the post-test scores. The same results are available for the STEM attitudes scale's sub-factors of science, engineering, technology, mathematics and 21 st-century skills. When the scale and sub-dimensions before and after the experiment are compared, it is noteworthy that although there are more pre-service teachers in the positive rank, there are also pre-service teachers in the negative rank (19 pre-service teachers), especially in the science sub-dimension.

Arithmetic means and standard deviations of pre-test and post-test scores pre-service science teachers have achieved from the STEM Attitude Scale and its sub-factors are given in Table 6. 
Table 6. Arithmetic means and standard deviations that pre-service teachers have achieved from STEM Attitude Scale and sub-factors

\begin{tabular}{|l|l|l|l|l|}
\hline \multirow{2}{*}{ STEM Attitude Scale and sub-factors } & \multicolumn{2}{|c|}{ Pre-Test } & \multicolumn{2}{c|}{ Post-Test } \\
\cline { 2 - 5 } & Mean & SD & Mean & SD \\
\hline Science sub-factor & 38.12 & 5.59 & 40.22 & 4.12 \\
\hline Engineering and technology sub-factor & 33.51 & 5.86 & 38.50 & 6.04 \\
\hline Mathematics sub-factor & 30.01 & 5.7 & 33.89 & 6.09 \\
\hline 21st century skills sub-factor & 45.12 & 6.79 & 49.95 & 4.72 \\
\hline Total Inventory & 146.77 & 18.01 & 162.57 & 16.85 \\
\hline
\end{tabular}

The results of the Wilcoxon Signed Rank Test for Paired Samples, which is conducted for the significance of the difference between pre-test and post-test average scores belonging to the STEM attitude scale and its sub-factors, are given in Table 7.

Table 7. STEM Attitude Scale Scores of Wilcoxon Signed Rank Test Results before and after the experiment

\begin{tabular}{|c|c|c|c|c|c|c|}
\hline & Posttest-Pre test & $\mathrm{n}$ & Mean Rank & Sum of Ranks & $\mathrm{z}$ & $\mathrm{p}$ \\
\hline \multirow{3}{*}{ STEM Attitude Scale } & Negative Ranks & 11 & 25.45 & 280.0 & $5.27 *$ &, 000 \\
\hline & Positive Ranks & 55 & 35.11 & 1931.0 & & \\
\hline & Ties & 0 & & & & \\
\hline \multirow{3}{*}{ Science sub-factor } & Negative Ranks & 19 & 26.82 & 509.5 & $2.99 *$ & ,003 \\
\hline & Positive Ranks & 41 & 32.21 & 1320.5 & & \\
\hline & Ties & 6 & & & & \\
\hline \multirow{3}{*}{ Engineering and technology sub-factor } & Negative Ranks & 12 & 20.58 & 247.0 & $4.92 *$ &, 000 \\
\hline & Positive Ranks & 48 & 32.98 & 1583.0 & & \\
\hline & Ties & 6 & & & & \\
\hline \multirow{3}{*}{ Mathematics sub-factor } & Negative Ranks & 12 & 21.71 & 260.5 & $4.50^{*}$ &, 000 \\
\hline & Positive Ranks & 45 & 30.94 & 1392.5 & & \\
\hline & Ties & 9 & & & & \\
\hline \multirow{3}{*}{21 st century skills sub-factor } & Negative Ranks & 13 & 20.92 & 272.0 & $4.73^{*}$ &, 000 \\
\hline & Positive Ranks & 47 & 33.15 & 1558.0 & & \\
\hline & Ties & 6 & & & & \\
\hline
\end{tabular}

Note. ${ }^{*}$ Based on negative ranks. 


\section{Mll Macrothink}

Wilcoxon Signed-Rank test results were given in the Table 7 that is about if the STEM attitudes of pre-service science teachers show a significant difference before and after the process of designing a scenario-based STEM project. The result of the analysis shows that there is a significant difference between pre-service science teachers' pre-test and post-test scores in the STEM attitudes scale, $\mathrm{z}=5.27, \mathrm{p}<.05$. When the mean rank and sum of ranks are taken into consideration, they evidence that this difference is in support of the post-test scores. The same results are available for the STEM attitudes scale's sub-factors of science, engineering, technology, mathematics and 21st-century skills. When the scale and sub-dimensions before and after the experiment are compared, it is noteworthy that although there are more pre-service teachers in the positive rank, there are also pre-service teachers in the negative rank (19 pre-service teachers), especially in the science sub-dimension.

Arithmetic means and standard deviations of pre-test and post-test scores pre-service science teachers have achieved in the Integrative STEM Teaching Intentions Questionnaire and its sub-factors are given in Table 8.

Table 8. Arithmetic means and standard deviations that pre-service teachers have achieved from the Integrative STEM Teaching Intention Questionnaire and sub-factors

\begin{tabular}{|l|l|l|l|l|}
\hline \multirow{2}{*}{ Integrative STEM Teaching Intention Scale and sub-factors } & \multicolumn{2}{|c|}{ Pre-Test } & \multicolumn{3}{c|}{ Post-Test } \\
\cline { 2 - 6 } & Mean & SD & Mean & SD \\
\hline Knowledge & 24.22 & 2.48 & 25.48 & 2.25 \\
\hline Value & 38.22 & 3.66 & 39.37 & 2.83 \\
\hline Attitude & 36.25 & 5.18 & 37.89 & 5.11 \\
\hline Subjective norm & 26.27 & 4.21 & 29.18 & 3.45 \\
\hline Perceived behavioral control and behavioral intention & 63.04 & 4.63 & 65.00 & 5.12 \\
\hline Total Inventory & 186.81 & 17.27 & 196.93 & 15.64 \\
\hline
\end{tabular}

Note. ${ }^{*}$ Based on negative ranks. 
Table 9. Integrative STEM Teaching Intention Scale Scores of Wilcoxon Signed Rank Test Results before and after the experiment

\begin{tabular}{|c|c|c|c|c|c|c|}
\hline \multicolumn{2}{|l|}{ Posttest-Pretest } & $\mathrm{n}$ & Mean Rank & Sum of Ranks & $\mathrm{z}$ & $\mathrm{p}$ \\
\hline \multirow{3}{*}{$\begin{array}{l}\text { Integrative STEM } \\
\text { Teaching Intention Scale }\end{array}$} & Negative Ranks & 17 & 25.47 & 433.0 & $4.18 *$ & .000 \\
\hline & Positive Ranks & 48 & 35.67 & 1712.0 & & \\
\hline & Ties & 1 & & & & \\
\hline \multirow[t]{3}{*}{ Knowledge } & Negative Ranks & 13 & 19.46 & 253.0 & $3.74 *$ & .000 \\
\hline & Positive Ranks & 37 & 27.62 & 1022.0 & & \\
\hline & Ties & 16 & & & & \\
\hline \multirow[t]{3}{*}{ Value } & Negative Ranks & 16 & 28.06 & 449.0 & $2.19 *$ & .028 \\
\hline & Positive Ranks & 36 & 25.81 & 929.0 & & \\
\hline & Ties & 14 & & & & \\
\hline \multirow[t]{3}{*}{ Attitude } & Negative Ranks & 16 & 29.75 & 476.0 & $2.47 *$ & .013 \\
\hline & Positive Ranks & 39 & 27.28 & 1064.0 & & \\
\hline & Ties & 11 & & & & \\
\hline \multirow[t]{3}{*}{ Subjective norm } & Negative Ranks & 15 & 18.80 & 282.0 & $4.56^{*}$ & .000 \\
\hline & Positive Ranks & 44 & 33.82 & 1488.0 & & \\
\hline & Ties & 7 & & & & \\
\hline \multirow{3}{*}{$\begin{array}{l}\text { Perceived behavioral } \\
\text { control and behavioral } \\
\text { intention }\end{array}$} & Negative Ranks & 11 & 28.64 & 315.0 & $3.56^{*}$ & .000 \\
\hline & Positive Ranks & 42 & 26.57 & 1116.0 & & \\
\hline & Ties & 13 & & & & \\
\hline
\end{tabular}

Wilcoxon Signed-Rank test results were given in the Table 9 that is about if integrative STEM teaching intentions of pre-service science teachers shows a significant difference before and after the process of designing scenario-based STEM projects. The result of the analysis shows that there is a significant difference between pre-service science teacher's scores of the pre-test and post-test in the integrative STEM teaching intentions scale, $\mathrm{z}=4.18$, $\mathrm{p}<.05$. When the mean rank and sum of ranks are considered, this difference is in favor of the post-test score. The same results are available for the integrative STEM teaching intentions scale sub-factors of knowledge, value, attitude, subjective norm, perceived behavioral control, and behavioral intentions. When the scores before and after the experiment are compared, it is seen that 17 preservice teachers ranked negative in the total score of the scale. There are preservice teachers who are in the negative rank in the sub-dimensions of the scale. 


\section{Discussion}

After analyzing the findings obtained by the research questions and the purposes of the study, the following results were obtained.

The first result obtained from the study is that there has been a significant increase in 21 st-century skills of pre-service teachers, their 21 st-century skill sub-factors of learning and innovation skills, life and career skills, information, media, and technology skills. In the related literature it is stated that STEM-based activities help participants to develop 21 st-century skills such as collaboration and communication (Karahan, Canbazoğlu-Bilici, \& Ünal, 2015), creative thinking, critical thinking, and problem-solving (Bybee, 2010; Şahin, Ayar, \& Adıguzel, 2014; Morrison, 2006; Lawanto et al., 2013; Y1ldırım \& Altun, 2015; Knezek, Christensen, Tyler-Wood, \& Periathiruvadi, 2013; Tseng, Chang, Lou, \& Chen, 2013). Wan Husin et al. (2016), who conducted a similar study with middle school students, found that the 21 st-century skills of the students improved with the Project-Oriented Problem Based Learning (POPBL) integrated with STEM education program. One of the most important goals of STEM education is to contribute to the development of 21 st-century skills of students (Capraro \& Jones, 2013; Çepni \& Ormanc1, 2017). As students learn by solving problems with STEM education, they become problem solvers in daily life who can adopt these solutions to new situations (Morrison, 2006; Dewaters \& Powers, 2006). With STEM, students can solve problems related to daily life, thus improving their 21 st-century skills (Hmelo-Silver, 2004). In the scope of the present research, the pre-service teachers identified the problem based on the scenario related to daily life and design projects in which they used engineering design processes to solve this problem. In this program, pre-service teachers first defined the daily life problem. Then, they designed projects using the problem situation in question, ask, imagine, plan, create, and improve the engineering design process. Research findings show that this program has a positive effect on pre-service science teachers' perceptions of 21 st-century competence. Research findings show that this program has a significant consequence on pre-service science teachers' perceptions of 21 st-century skill competence. To achieve this, trainee teachers had to make a connection between the state of the problem and the situations they experienced in real life. This association was kept with scenarios. With design-based STEM, 21st-century skills can be advanced (Felix, Bandstra, \& Strosnider, 2010). Pre-service science teachers had to use many 21 st century skills throughout this process. The positive increase in the 21 st-century skill perceptions of pre-service teachers urges them that they have to use these skills in the experimental application process. It is critical for science teachers who will train future generations to have advanced 21 st-century skills.

The second result obtained from the study is that there has been a significant increase in the STEM attitudes of pre-service science teachers. There has also been a significant increase in their STEM attitudes towards the sub-factors of science, engineering, technology, mathematics, and 21 st-century skills. There has been a positive progress in the 21 st-Century skills sub-factor of pre-service teachers. Kan and Murat (2018) found a moderate positive relationship between STEM attitudes and 21st-century efficacy perceptions. Teachers' negative attitudes towards STEM cause less time spent in science and mathematics teaching 
and less focus on students' participation in authentic inquiry-based activities (Appleton \& Kindt, 2002). Teachers' attitudes are related to teaching practices in STEM (Thibaut et al., 2018). For this reason, it is crucial to determine and develop teachers' and pre-service teachers' attitudes toward STEM. Similarly, activities based on STEM education at different educational levels positively affect their attitudes towards STEM education (Rehmat, 2015; Gülhan \& Şahin, 2016; Yamak, Bulut, \& Dündar, 2014; Mixan \& Yurdakul, 2017; Uğraş, 2018; Reid-Griffin, 2019; Guzey, Moore, Harwell, \& Moreno; 2016; Karahan et al., 2014). Activities using STEM in the problem-based learning environment affect students' attitudes positively towards STEM (Alic1, 2018). These results were consistent with relevant studies. STEM-based applications have also improved the STEM attitudes of pre-service science teachers (Wahono \& Chang, 2018). Most of the teachers who participated in STEM training sessions had positive attitudes (Affouneh et al., 2020). Active involvement of pre-service science teachers in the process based on Cunningham (2009), and engineering design process steps may have been effective in the positive change in their attitudes. Methodology lessons can play an essential role in addressing teachers' attitudes toward STEM. It is assumed that the teachers who develop positive attitudes towards STEM will include STEM in their teaching in the future (Adams et al., 2014). Tseng et al. (2013) concluded that project-based learning practices improved the STEM attitudes positively in the first-year students of the technology institute. Similarly, Çetin and Kahyaoğlu (2018) concluded those pre-service science teachers' attitudes towards science, engineering technology, and 21st-century skills of STEM-based activities increased. However, in these studies, it was determined that unlike the results of the research, their attitudes towards mathematics decreased. The fact that the number of pre-service teachers who were in negative ranks in the comparison of pretest-posttest in the whole scale were especially in the science sub-dimension draws attention. This situation may have had a negative effect on the attitudes of pre-service teachers preparing STEM projects intensively for one semester, that is, because of their engaging themselves in similar activities for a long time.

The third result obtained from the study is that there has been a significant increase in integrative STEM Teaching Intentions and its sub-factors of knowledge, value, attitude, subjective norm, perceived behavioral control and behavioral intention. Teaching a course well is a prerequisite for accumulating interdisciplinary knowledge. To improve teachers' involvement in STEM teaching, further studies on teacher professional development are needed to investigate how to develop their pedagogical design qualifications and collaboration recognition (Dong et al., 2019). Similarly, Aygen (2018), who examined the effect of STEM activities with pre-service science teachers, concluded that the group in which the activities were applied had higher integrated STEM teaching orientations, but did not examine the change in sub-dimensions. To a similar result to the research results, Timur and Belek (2020) concluded that STEM applications with pre-service science teachers have a positive effect on STEM teaching orientations. While the researchers found a significant increase in knowledge, attitude, and subjective norm sub-dimensions, they did not find a statistically significant increase in value, perceived behavioral control, and behavioral intention sub-factors. In the present study, which investigated the effect of similar design-based STEM activities on pre-service science teachers' orientation towards integrated 
STEM teaching, the statistical effect of the activities on the sub-dimensions of value, subjective norm, perceived behavioral control and behavioral intention was significant. There is no significant increase in the knowledge and attitude dimensions of the scale (Özkızılc1k \& Cebesoy, 2020). Dissimilar results were in sub-dimensions in various studies. This may be due to the different class levels of the study groups or the various activities used in experimental practice. In the implementation of STEM education plans for primary and secondary schools, the development of teachers' teaching skills is emphasized (Kuenzi, 2008). The explanations of the pre-service teachers about STEM education may also reflect their general attitudes towards STEM (Lin \& Williams, 2016). STEM applications improve the perceptions of teaching competencies (Pinnell et al., 2013). STEM education has also a positive effect on teaching science (El-Deghaidy \& Mansour, 201; Becker \& Park, 2011). In line with the results of the research, especially, the STEM awareness and intentions of teaching STEM subjects tended to increase after attending the methodology course (Karışan et al., 2019). Adams et al. (2014), revealed that place-based STEM teaching has a positive effect on a pre-service teacher's intentions to design and implement STEM activities. In the STEM teaching intentions scale total score, the number of pre-service teachers in positive rank is higher, but the number of pre-service teachers in the negative rank is also remarkable. This may be due to the fact that teacher candidates, who learned and applied STEM in all its dimensions, evaluated their own self-efficacy, content knowledge and pedagogical content knowledge in depth. It was emphasized that the reason why some pre-service teachers do not want to use STEM in their lessons is due to their lack of content knowledge (Y1ldırım \& Türk, 2018), and teachers do not want to integrate STEM into their lessons due to their low self-efficacy perceptions despite their positive views on STEM (Y1ldırım, 2016).

\section{Conclusion}

This study confirms the impact of STEM project design process supported by a scenario to develop the 21 st-century competency perceptions of pre-service science teachers, STEM attitudes, and integrated STEM teaching orientations. Pre-service science teachers improve the perceptions of 21 st-century skill competence and learning and innovation skills, life and career skills, information, media, and technology skills, which are sub-factors of the scale.

The scenario-based STEM project design process caused a positive change in the STEM attitude and science, engineering and technology, mathematics, and 21st-century skills, which are sub-factors of the STEM attitudes of pre-service science teachers.

The integrative STEM Teaching Intentions and its sub-factors of knowledge, value, attitude, subjective norm, perceived behavioral control and behavioral intentions are also significantly different in favor of post-tests.

It contributes to the current knowledge by asserting the scenario-based STEM project design process has a positive effect on pre-service science teachers' 21 st-century skills and competencies, integrative STEM teaching intentions, and STEM attitude. Thus, teachers who are educated in terms of various skills will be trained and their desire to integrate STEM into their professional lives will increase with their positive attitudes. In this study, pre-service teachers followed the steps of the engineering design process and searched for solutions to 
scenarios involving real-life problems. This situation has improved their 21 st-century skills perceptions. This emphasizes the importance of including activities for preparing STEM projects supported by the script in science teacher education. It is thought that if the pre-service teachers are aware of STEM, project-based learning, problem-based learning, and inquiry-based learning methods, it will be easier to apply them in their lessons. The present study, therefore, recommends that the scenario-based STEM project design process can be used in pre-service teachers training courses.

\section{Limitations}

The findings in this study should be interpreted considering several limitations. First, in this study, a single group of weak experimental design can be considered the limitation of the study. However, this situation stems from the fact that a comparison with a control group is not desired for the study. Additionally, the issue of how the activities to be applied to the control group should differ from the experimental group prevented the researchers from conducting this study with an experimental control group. Since it would not be meaningful to determine STEM attitudes and integrated STEM teaching orientations with laboratory activities that were not developed based on STEM, and to prevent bias in favor of the experimental group, the study was designed as a single group.

Second, this study continued for an academic half-year. However, with the announcement of a pandemic in that semester, the practices that started through face-to-face education had to be completed through distance education process, since the lessons were conducted through distance education. Furthermore, the pre-service teachers had difficulties in procuring materials due to the curfew restrictions and had to choose easily accessible materials as much as possible. The development and change of pre-service teachers in a year have been examined. Considering that especially the improvement of affective characteristics takes a long time, the permanent effect of development and change can be discussed by applying follow-up tests. Finally, in this study, data were collected quantitatively. It was assumed that the 21 st-century competency perceptions, STEM attitude, and integrated STEM teaching orientations of pre-service teachers can be measured with the items in the scale used. It is critical to diversify the studies using scenario-based STEM project applications by using qualitative data collection tools to support quantitative data and to make a more in-depth analysis. For this reason, a mixed-method design can be used in future studies. Sharing the research finding with science teachers, they can be motivated to design a scenario-based STEM project.

\section{Acknowledgements}

The author would like to acknowledge the pre-service science teachers for their participation in the research. I thank Dr. Mehmet Karabal for his technical assistance in preparing Figure 1.

\section{References}

Adams, A. E., Miller, B. G., Saul, M., \& Pegg, J. (2014). Supporting elementary pre-service teachers to teach stem through place-based teaching and learning experiences. Electronic Journal of Science Education, 18(5), 1-22. 
Affouneh, S., Salha, S., Burgos, D., Khlaif, Z. N., Saifi, A. G., Mater, N., \& Odeh, A. (2020). Factors that foster and deter STEM professional development among teachers. Science Education, 104(5), 857-872. https://doi.org/10.1002/sce.21591

Akgündüz, D., Aydeniz, M., Çakmakçı, G., Çavaş, B., Çorlu, M. S., Öner, T., \& Özdemir, S. (2015). Turkey STEM Education Report: Is the Day fashion? Or Do I Need? İstanbul: Aydın Üniversitesi.

Al Salami, M. K., Makela, C. J., \& de Miranda, M. A. (2017). Assessing changes in teachers' attitudes toward interdisciplinary STEM teaching. International Journal of Technology Design and Education, 27, 63-88. https://doi.org/10.1007/s10798-015-9341-0

Alic1, M. (2018). The effect of STEM education in problem-based learning environment on attitude, career perception and occupational interest and student views (Unpublished master's thesis, Fen Bilimleri Enstitüsü Kırıkkale Üniversitesi, Kırıkkale).

Anagün, Ş. S., Atalay, N., Kılıç, Z., \& Yaşar, S. (2016). Developing 21st century skills competence perceptions scale for prospective teachers: A validity and reliability study. Pamukkale Ĕ̈itim Fakültesi Dergisi, 40, 160-175.

Anugerahwati, M. (2019). Integrating the $6 \mathrm{cs}$ of the 21 st century education into the english lesson and the school literacy movement in secondary schools. KnE Social Sciences, 3(10), 165. https://doi.org/10.18502/kss.v3i10.3898

Appleton, K., \& Kindt, I. (2002). Beginning elementary teachers' development as teachers of science. Journal of Science Teacher Education, 13(1), 43-61. https://doi.org/10.1023/A:10151 81809961

Aslan-Tutak, F., Akaygün, S., \& Tezsezen, S. (2017). Collaborative STEM (Science, Technology, Engineering, Mathematics) Education Practice: Investigation of Pre-service Chemistry and Mathematics Teachers' STEM Awareness. Hacettepe Üniversitesi Ĕgitim Fakültesi Dergisi, 32(4), 794-816.

Aydın, G., Saka, M., \& Guzey, S. (2017). Science, technology, engineering, mathematic (STEM) attitude levels in grades 4th-8th. Mersin University Journal of the Faculty of Education, 13(2), 787-802. https://doi.org/10.17860/mersinefd.290319

Aygen, M. B. (2018). STEM applications to support the integrated teaching knowledge of pre-service science teachers (Unpublished Master's thesis, Frrat Üniversitesi, Eğitim Bilimleri Enstitüsü, Elazı $\breve{g})$.

Baran, E., Canbazoğlu Bilici, S., \& Mesutoğlu, C. (2015). Science, technology, engineering and mathematics (STEM) spot development activity. Araştırma Temelli Etkinlik Dergisi, 5(2), 60-69.

Becker, K., \& Park, K. (2011). Effects of integrative approaches among science, technology, engineering, and mathematics (STEM) subjects on students' learning: A preliminary meta-analysis. Journal of STEM Education: Innovations \& Research, 12(5/6), 23-37. 
Bingolbali, E., Monaghan, J., \& Roper, T. (2007). Engineering students' conceptions of the derivative and some implications for their mathematical education. International Journal of Mathematical Education in Science and Technology, 38(6), 763-777. https://doi.org/10.1080/ 00207390701453579

Blumenfeld, P. C., Soloway, E., Marx, R. W., Krajcik, J. S., Guzdial, M., \& Palincsar, A. (1991). Motivating project-based learning: Sustaining the doing, supporting the learning. Educational Psychologist, 26(3-4), 369-398. https://doi.org/10.1207/s15326985ep2603\&4_8

Bozkurt, E. (2014). The effect of engineering design based science education on preservice science teachers' decision making skills, scientific process skills and perceptions towards the process (Unpublished $\mathrm{PhD}$ Thesis, Gazi University, Institute of Educational Sciences, Ankara).

Breiner, J. M., Harkness, S. S., Johnson, C. C., \& Koehler, C. M. (2012). What is STEM? A discussion about conceptions of STEM in education and partnerships. School Science and Mathematics, 112(1), 3-11. https://doi.org/10.1111/j.1949-8594.2011.00109.x

Bryan, L. A., Moore, T. J., Johnson, C. C., \& Roehrig, G. H. (2015). Integrated STEM education. In C. C. Johnson, E. E. Peters-Burton, \& T. J. Moore (Eds.), STEM roadmap: A framework for integration (pp. 23-37). London: Taylor \& Francis. https://doi.org/10.4324/ 9781315753157-3

Büyüköztürk, Ş., Kılıç Çakmak, E., Akgün, Ö. E., Karadeniz, Ş., \& Demirel, F. (2008). Scientific research methods. Ankara: Pegem Akademi.

Bybee, R. W. (2010). The teaching of science: 21st century perspectives. Arlington, Virginia: NSTA Press.

Capraro, M. M., \& Jones, M. (2013). Interdisciplinary STEM project-based learning in STEM Project-Based Learning, Rotterdam (pp. 51-58). The Netherlands: Sense Publishers. https://doi.org/10.1007/978-94-6209-143-6_6

Capraro, R. M., Capraro, M. M., \& Morgan, J. R. (2013). STEM project-based learning: An integrated science, technology, engineering, and mathematics (STEM) approach. Rotterdam: Sense. https://doi.org/10.1007/978-94-6209-143-6

Çepni, S. (2018). STEM training from theory to practice. Ankara: Pegem Akademi. https://doi.org/10.14527/9786052410561.01

Çepni, S., \& Ormanc1, Ü. (2018). The world of the future. In Ç. Salih (Ed.), From Theory to Practice in Stem Education (pp. 1-37). Ankara: Pegem Akademi.

Çetin, A., \& Kahyaoğlu, M. (2018). The Effect of STEM-Based Activities on Preservice Science Teachers' Attitudes Towards Science, Mathematics, Engineering and Technology and 21st Century Skills. Ekev Akademi Dergisi, 22(75), 15-28. https://doi.org/10.17753/Ekev952

Çevik, M., Danıştay, A., \& Yağcı, A. (2017). Evaluation of secondary school teachers' STEM (Science-Technology-Engineering-Mathematics) awareness according to different variables. 
Sakarya University Journal of Education, 7(3), 584-599. https://doi.org/10.19126/suje. 335008

Christensen, R., Knezek, G., \& Tyler-Wood, T. (2015). Alignment of hands-on STEM engagement activities with positive STEM dispositions in secondary school students. Journal of Science Education and Technology, 24(6), 898-909. https://doi.org/10.1007/s10956-0159572-6

Cook, T. D., \& Campbell, D. T. (1979). The design and conduct of true experiments and quasi-experiments in field settings. Reproduced in part in Research in Organizations: Issues and Controversies. Goodyear Publishing Company.

Çorlu, M. S., Capraro, R. M., \& Capraro, M. M. (2014). Introducing STEM Education: Implications for Educating Our Teachers for the Age of Innovation. Education and Science, 39(171), 74-85.

Cunningham, C. M. (2009). Engineering is elementary. The Bridge, 30(3), 11-17.

Dewaters, J., \& Powers, S. (2006). Improving science literacy through project-based K-12 outreach efforts that use energy and environmental themes. Proceedings of the 113th Annual ASEE Conference \& Exposition, Chicago, IL. https://doi.org/10.18260/1-2--158

Diggs, V. (2009). Ask-think-create: The process of inquiry. Knowledge Quest, 37(5), 30-33.

Dong, Y., Xu, C., Song, X., Fu, Q., Chai, A. S., \& Huang, Y. (2019). Exploring the Effects of Contextual Factors on In-Service Teachers' Engagement in STEM Teaching. Asia-Pacific Education Research, 28, 25-34. https://doi.org/10.1007/s40299-018-0407-0

El-Deghaidy, H., \& Mansour, N. (2015). Science teachers' perceptions of STEM Education: Possibilities and challenges. International Journal of Learning and Teaching, 1(1), 51-54. https://doi.org/10.18178/ijlt.1.1.51-54

Faber, M., Unfried, A., Wiebe, E. N., Corn, J. Townsend, L. W., \& Collins, T. L. (2013). Student attitudes toward STEM: the development of upper elementary school and middle/high school student surveys. 120th ASSE Annual Conference \& Exposition, Atlanta. https://doi.org/10.18260/1-2--22479

Felix, A. L., Bandstra, J. Z., \& Strosnider, W. H. J. (2010). Design-Based science for STEM student recruitment and teacher professional development. MidAtlantic American Society for Engineering Education Conference, Philadelphia.

Gelen, B., Akçay, B., Tiryaki, A., \& Benek, İ. (2019). Science Teacher Candidates' Self-Efficacy Scale for Science-Technology-Engineering-Mathematics (STEM): Adaptation to Turkish, Validity and Reliability Study. Eğitimde Kuram ve Uygulama, 15(1), 88-107. https://doi.org/10.17244/eku.395204

Görgülü Arı, A., \& Hayır Kanat, M. (2020). Teacher Candidates' Views on Covid-19 (Coronavirus). Yüzüncü Yıl Üniversitesi Sosyal Bilimler Enstitüsü Dergisi, 459-492.

Gülgün, C., Yılmaz, A., \& Çağlar, A. (2017). Teacher opinions about the qualities required in 
STEM activities applied in the science course. Journal of Current Researches on Social Sciences, 7(1), 460-478.

Gülhan, F., \& Şahin, F. (2016). The effects of science-technology-engineering-math (STEM) integration on 5th grade students' perceptions and attitudes towards these areas. Journal of Human Sciences, 13(1), 602-620. https://doi.org/10.14687/ijhs.v13i1.3447

Günbatar, M. S., \& Bakırc1, H. (2019). STEM teaching intention and computational thinking skills of pre-service teachers. Education and Information Technologies, 24(2), 1615-1629. https://doi.org/10.1007/s10639-018-9849-5

Gunn, J. (2017). The Evolution of STEM and STEAM in the US. Retrieved April 12, 2020, from https://education.cu-portland.edu/blog/classroom-resources/evolution-of-stem-and-steam -in-the-united-states

Guzey, S. S., Moore, T. J., Harwell, M., \& Moreno, M. (2016). STEM integration in middle school life science: Student learning and attitudes. Journal of Science Education and Technology, 25(4), 550-560. https://doi.org/10.1007/s10956-016-9612-x

Hacıoglu, Y., Yamak, H., \& Kavak, N. (2016a). Teachers' views on science education based on engineering design. Bartın Üniversitesi Eğitim Fakültesi Dergisi, 5(3), 807-830. https://doi.org/10.14686/buefad.v5i3.5000195411

Hacıŏlu, Y., Yamak, H., \& Kavak, N. (2016b). Pre-service science teachers' cognitive structures regarding science, technology, engineering, mathematics (STEM) and science education. Journal of Turkish Science Education, 88-102.

Hacıömeroğlu, G., \& Bulut, A. S. (2016). Integrative Stem Teaching Intentıon Questionnaire: A Validity And Relaibility Study Of The Turkish Form. Journal of Theory and Practice in Education, 12(3), 654-669.

Han, S., Yalvaç B., Capraro, M. M., \& Capraro, R. M. (2015). In-service teachers' 1mplementation and understanding of stem project based learning. Eurasia Journal of Mathematics, Science \& Technology Education, 11(1), 63-76. https://doi.org/10.12973/eurasia. 2015.1306a

Hiong, L. C., \& Osman, K. (2013). A conceptual framework for the integration of 21st century skills in biology education. Research Journal of Applied Sciences, Engineering and Technology, 6(16), 2976-2983. https://doi.org/10.19026/rjaset.6.3681

Hmelo Silver, C. E. (2004). Problem-based learning: What and how do students learn? Educational Psychology Review, 16(3), 235-266. https://doi.org/10.1023/B:EDPR.0000034 022.16470.f3

Hsu, M.-C., Purzer, S., \& Cardella, M. E. (2011). Elementary Teachers' Views about Teaching Design, Engineering and Technology. Journal of Pre-College Engineering Education Research, 1(2), 31-39.

Ibrahim, N., \& Halim, S. A. (2013). Implementation of Project-Oriented Problem-Based 
Learning (POPBL) in Introduction to Programming Course. International Research Symposium on Problem-based Learning, 4, 279-288.

Jacobson, M. J., \& Wilensky, U. (2006). Complex systems in education: Scientific and educational importance and implications for the learning sciences. The Journal of the Learning Sciences, 15(1), 11-34. https://doi.org/10.1207/s15327809j1s1501_4

Kan, A. Ü., \& Murat, A. (2018). Investigation of prospective science teachers' 21st century skill competence perceptions and attitudes toward STEM. International Online Journal of Educational Sciences, 10(4), 251-272.

Kanematsu, H., \& Barry, D. M. (2016). The importance of STEM for modern education. STEM and ICT Education in Intelligent Environments (pp. 25-30). Springer, Cham. https://doi.org/10.1007/978-3-319-19234-5_4

Karahan, E., Canbazoglu Bilici, S., \& Unal, A. (2015). Integration of Media Design Processes in Science, Technology, Engineering, and Mathematics (STEM) Education. Eurasian Journal of Educational Research, 60, 221-240. https://doi.org/10.14689/ejer.2015.60.15

Karasar, N. (2010). Scientific research methods (21st ed.). Ankara: Nobel Yayın.

Karışan, D., \& Yurdakul, Y. (2017). The effects of microprocessors based science technology engineering and mathematics (STEM) investigations on 6th grade students' attitudes towards these subject areas. Adnan Menderes University Education Faculty Journal of Education Science, 8(1), 37-52.

Karışan, D., Macalalag, A., \& Johnson, J. (2019). The effect of methods course on preservice teachers' awareness and intentions of teaching science, technology, engineering, and mathematics (STEM) subjects. International Journal of Research in Education and Science, $5(1), 22-35$.

Kay, K. (2009). Middle schools preparing young people for 21 st century life and work. Middle School Journal, 40(5), 41-45. https://doi.org/10.1080/00940771.2009.11461691

Khalil, N., \& Osman, K. (2017). STEM-21CS module: Fostering 21st century skills through integrated STEM. K-12 STEM Education, 3(3), 225-233.

Knezek, G., Christensen, R., Tyler-Wood, T., \& Periathiruvadi, S. (2013). Impact of Environmental Power Monitoring Activities on Middle School Student Perceptions of STEM. Science Education International, 24(1), 98-123.

Kuenzi, J. J. (2008). Science, technology, engineering and mathematics (STEM) education: Background, federal policy, and legislative action. Washington, DC: Congressional Research Service. Retrieved from https://digitalcommons.unl.edu/crsdocs/35

Kumtepe, A. T., \& Genc Kumtepe, E. (2014). STEM in early childhood education: We talk the talk, but do we walk the walk? In H. Y. Yang, Z. Yang, D. Wu, \& S. Liu (Eds.), Transforming K-12 Classrooms with Digital Technology (pp. 140-163). New York, NY: IGI Global. https://doi.org/10.4018/978-1-4666-4538-7.ch008 


\section{Macrothink}

Journal of Educational Issues

ISSN 2377-2263

2020, Vol. 6, No. 2

Lawanto, O., Butler, D., Cartier, S. C., Santoso, H. B., Goodridge, W., Lawanto, K. N., \& Clark, D. (2013). Pattern of Task Interpretation and Self-Regulated Learning Strategies of High School Students and College Freshmen during an Engineering Design Project. Journal of Stem Education, 14(4), 15-27.

Lin, K. Y., \& Williams, P. J. (2015). Taiwanese Preservice Teachers' Science, Technology, Engineering, and Mathematics Teaching Intention. International Journal of Science and Mathematics Education, 1-16.

Marulcu, İ., \& Sungur, K. (2012). Investigation of science teacher candidates' engineer and engineering perceptions and their perspective on engineering-design as a method. Afyon Kocatepe Üniversitesi Fen ve Mühendislik Bilimleri Dergisi, 12(1), 13-23.

Ministry of Education. (2016). STEM Education Report. Retrieved from http://yegitek.meb. gov.tr/STEM_Egitimi_Raporu.pdf

Moomaw, S., \& Davis, J. A. (2010). STEM comes to preschool. YC Young Children, 65(5), 12-18.

Morrison, J. (2006). Attributes of STEM education. TIES STEM education monograph series. Baltimore, MD: Teaching Institute for Excellence in STEM.

Motallebzadeh, K., Ahmadi, F., \& Hosseinnia, M. (2018). Relationship between 21st century skills, speaking and writing skills: A structural equation modelling approach. International Journal of Instruction, 11(3), 265-276. https://doi.org/10.12973/iji.2018.11319a

National Research Council. (2011). Successful K-12 STEM education: Identifying effective approaches in science, technology, engineering, and mathematics. National Academies Press.

Oner, A. T., Navruz, B., Biçer, A., Peterson, C. A., Capraro, R. M., \& Capraro, M. M. (2014). T-STEM academies' academic performance examination by education service centers: A longitudinal study. Turkish Journal of Education, 3(4), 40-51. https://doi.org/10.19128/ turje. 35590

Özbilen, A. G. (2018). Teacher opinions and awareness about stem education. Scientific Educational Studies, 2(1), 1-21.

Özçakır-Sümen, Ö., \& Çalisici, H. (2016). Pre-Service Teachers' Mind Maps and Opinions on STEM Education Implemented in an Environmental Literacy Course. Educational sciences: Theory and Practice, 16(2), 459-476.

Özkızılcık, M., \& Cebesoy, Ü. B. (2020). Investigation of the Effect of Design Based STEM Activities on Pre-service Science Teachers' Problem Solving Skills and STEM Teaching Orientations. Uludă̆ Üniversitesi Ĕ̈itim Fakültesi Dergisi, 33(1), 177-204.

Öztürk, S. C. (2018). The problem solving process of STEM education science teacher candidates and its impact on critical thinking skills (Unpublished Master's thesis, Erzincan Binali Yıldırım Üniversitesi Fen Bilimleri Enstitüsü, Erzincan).

Pinnell, M., Rowley, J., Preiss, S., Franco, S., Blust, R., \& Beach, R. (2013). Bridging the gap 
between engineering design and PK-12 curriculum development through the use of the STEM education quality framework. Journal of STEM Education, 14(4), 28-35.

Pryor, B. W., Pryor, C. R., \& Kang, R. (2016). Teachers' thoughts on integrating STEM into social studies instruction: Beliefs, attitudes, and behavioral decisions. The Journal of Social Studies Research, 40(2), 123-136. https://doi.org/10.1016/j.jssr.2015.06.005

Rehmat, A. P. (2015). Engineering the path to higher-order thinking in elementary education: a problem-based learning approach for stem integration. (Doctoral dissertation, ProQuest Dissertations and Theses database, 1734004410).

Reid-Griffin, A. (2019). Mentoring: Helping youth make a difference in STEM. Journal of Education in Science, Environment and Health, 5(1), 1-11. https://doi.org/10.21891/jeseh. 478308

Rotherham, A. J., \& Willingham, D. (2009). 21st century. Educational Leadership, 67(1), 16-21.

Şahin, A., Ayar, M. C., \& Adıguzel, T. (2014). STEM related after-school program activities and associated outcomes on student learning. Educational Sciences: Theory \& Practice, 14(1), 309-322. https://doi.org/10.12738/estp.2014.1.1876

Sanders, M. (2009). Integrative STEM education: Primer. The Technology Teacher, 68(4), 20-26.

Sivrikaya, S. O. (2019). Investigation of high school students' attitudes towards STEM. OPUS Uluslararası Toplum Araştırmaları Dergisi, 11(18), 914-934.

Thibaut, L., Ceuppens, S., De Loof, H., De Meester, J., Goovaerts, L., Struyf, A., \& Depaepe, F. (2018). Integrated STEM education: A systematic review of instructional practices in secondary education. European Journal of STEM Education, 3(1), 02-12. https://doi.org/ $10.20897 /$ jsteme/85525

Timur, B., \& Belek, F. (2020). Investigation of the effects of STEM activities on pre-service teachers' self-efficacy beliefs and fetem education orientations. Pamukkale Üniversitesi Ĕ̈itim Fakültesi Dergisi, 50, 315-332.

Tseng, K. H., Chang, C. C., Lou, S. J., \& Chen, W. P. (2013). Attitudes towards science, technology, engineering and mathematics (STEM) in a project-based learning (PjBL) environment. International Journal of Technology and Design Education, 23(1), 87-102. https://doi.org/10.1007/s10798-011-9160-x

Tsupros, N., Kohler, R., \& Hallinen, J. (2009). STEM education: A project to identify the missing components. Intermediate Unit, 1, 11-17.

Uğraş, M. (2018). The effect of STEM activities on STEM attitudes, scientific creavity and motivation beliefs of the students and their views on STEM education. International Online Journal of Educational Sciences, 10(5), 165-182. https://doi.org/10.15345/iojes.2018.05.012

Wahono, B., \& Chang, C. Y. (2018). Examining the relationship between science teachers' 
knowledge, attitude, and application of stem education. Proceedings of the 2018 International Conference of East-AsiaAssociation for Science Education (EASE), Hualien.

Wai, J., Lubinski, D., Benbow, C. P., \& Steiger, J. H. (2010). Accomplishment in science, technology, engineering, and mathematics (STEM) and its relation to STEM educational dose: A 25-year longitudinal study. Journal of Educational Psychology, 102(4), 860. https://doi.org/10.1037/a0019454

Wan Husin, W. N. F., Mohamad Arsad, N., Othman, O., Halım, I., Rasul, M. S., Osman, K., \& Iksan, Z. (2016). Fostering students' 21st century skills through Project Oriented Problem Based Learning (POPBL) in integrated STEM education program. Asia-Pacific Forum on Science Learning \& Teaching, 17(1), 60-77.

Wang, H. H., Moore, T. J., Roehrig, G. H., \& Park, M. S. (2011). STEM integration: Teacher perceptions and practice. Journal of Pre-College Engineering Education Research, 1(2), $1-13$.

White, D. W. (2014). What is STEM education and why is it important. Florida Association of Teacher Educators Journal, 1(14), 1-9.

Yamak, H., Bulut, N., \& Dündar, S. (2014). The impact of STEM activities on 5th grade students' scientific process skills and their attitudes towards science. Gazi Eğitim Fakültesi Dergisi, 34(2), 249-265. https://doi.org/10.17152/gefd.15192

Y1ldırım, B. (2016). An Analyses and Meta-Synthesis of Research on STEM Education. Journal of Education and Practice, 7(34), 23-33.

Y1ldırım, B. (2018). STEM education from theory to practice: A practice book. Ankara: Nobel Yayınları.

Y1ldirım, B., \& Altun, Y. (2015). Investigation of the Effects of STEM Education and Engineering Applications in the Science Laboratory Course. El-Cezerî Fen ve Mühendislik Dergisi, 2(2), 28-40.

Y1ldırım, B., \& Selvi, M. (2015). Adaptation of STEM Attitude Scale to Turkish. Turkish Studies-International Periodical for the Languages, Literature and History of Turkish or Turkic, 10(3), 1107-1120. https://doi.org/10.7827/TurkishStudies.7974

Y1ldırım, B., \& Türk, C. (2018). Pre-service primary school teachers' views about STEM education: An applied study. Trakya Üniversitesi Eğitim Fakültesi Dergisi, 8(2), 195-213.

Y1lmaz, N., \& Pekbay, C. (2017). A study on introducing a STEM activity with preservice science and primary mathematics teachers (pp. 518-519). International Congress on Politic, Economic and Social Studies, Sarajevo Bosnia Herzegovina. 


\section{Copyright Disclaimer}

Copyright for this article is retained by the author(s), with first publication rights granted to the journal.

This is an open-access article distributed under the terms and conditions of the Creative Commons Attribution license (http://creativecommons.org/licenses/by/3.0/). 